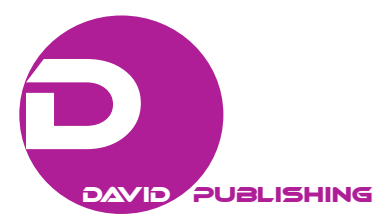

\title{
The Entrepreneurial Marketing Concept and Its Application by the International New Ventures
}

\author{
Izabela Kowalik, Elżbieta Duliniec \\ Warsaw School of Economics, Warsaw, Poland
}

\begin{abstract}
For the last two decades, there has been an ongoing research concerning the international new ventures (INV) or born global (BG) companies which are rapidly entering foreign markets. They face challenges connected with their marketing activity, because they launch relatively more product innovations in a shorter time than the gradually internationalized companies (GRAD). The entrepreneurial marketing (EM) concept could become a solution to some of these challenges, because of a greater entrepreneurial intensity (EI) and different decision-making approach than "classical" marketing concept. This study's aim is to analyze the EM concept and application of its elements by the INVs originating from Poland. Based on two computer-aided telephone interview (CATI) studies of INVs from the Polish industrial processing sector, the central elements of EM, applied by them, are explored, together with their relationship to INV performance. As it is shown, the INVs introduce significantly more product innovations than the gradually internationalized small and medium sized enterprises (SMEs). They often exceed competitors in the speed of launching innovations and are flexible in entering new markets. The entrepreneurial orientation (EO) indicators are at low to medium levels in all studied SMEs. However, the propensity to risk is slightly stronger in the INVs and correlated moderately with the financial performance. As the study shows, lack of emphasis on marketing planning and information gathering is the characteristic of the Polish INVs, which may testify to their effectual approach to decision making. Furthermore, similar as in the foreign-based INVs, there may exist a relationship between the application of the EM concept and performance of the Polish INVs, which, however, requires further study with respect to some mediating factors. It has been concluded that innovativeness of the product offering and propensity to risk seems to be the characteristic EM concept elements accompanying the rapid internationalization of INVs. The future research should focus on other elements of the EM-mix applied by INVs originating from emerging economies.
\end{abstract}

Keywords: entrepreneurial marketing (EM), international new ventures (INV), innovativeness

\section{Introduction}

There has, recently been an increase of scientific interest in the internationalization of small and medium sized enterprises (SMEs) and their activity on the foreign markets. As some internationalization studies show, among the small internationalizing companies, which often lack sufficient funds and experience, the challenges

Izabela Kowalik, Ph.D., associate professor, Institute of International Management and Marketing, Warsaw School of Economics, Warsaw, Poland.

Elżbieta Duliniec, Ph.D., full professor, Institute of International Management and Marketing, Warsaw School of Economics, Warsaw, Poland.

Correspondence concerning this article should be addressed to Izabela Kowalik, Institute of International Management and Marketing, Warsaw School of Economics, Madalinskiego St. 6/8, Warsaw, 02-554 Poland. E-mail: iza123@ sgh.waw.pl. 
connected with conducting effective marketing activity abroad are especially important (Luostarinen \& Gabrielsson, 2006). One solution to this problem can be the application of entrepreneurial marketing (EM) concept, which has recently been gaining popularity (Becherer, Haynes, \& Helms, 2008; Gilmore, 2011; Mort, Weerawardena, \& Liesh, 2012).

This study's aim is to analyze the concept of EM and its implementation by the international new ventures (INV), with a particular focus on such firms originating from Poland. In the last years, export has been the main factor contributing to the Polish gross domestic product (GDP) growth (Główny Urząd Statystyczny, 2014). In 2012, the annual SMEs' export volume increased by double the rate of the export increase in the large-sized Polish firms. The SMEs have been responsible for over $40 \%$ of the exports of Polish products and among them especially the small enterprises have been internationally active (Retrieved from http://www.parp.gov.pl/raport-o-stanie-sektora-malych-i-srednich-przedsiebiorstw-w-polsce-w-latach-2011-20 12). Thus, the focus of this study is on INVs defined as "business organizations that, from inception, seek to derive significant competitive advantage from the use of resources and the sale of outputs in multiple countries", also called "born global" (BG) enterprises (Oviatt \& McDougall, 1994; Crick, 2009). The phenomenon of early and quick internationalization of these firms raised attention of scholars two decades ago, as it is in opposition to the traditional incremental route of going international (Madsen \& Servais, 1997). Some of the recent studies (Jarosiński, 2013; Kowalik \& Baranowska-Prokop, 2013; Cieślik \& Kaciak, 2009) have shown that this internationalization route is also followed by the Polish SMEs. Therefore, it is interesting to find out what approach to marketing such companies apply and especially what elements of the EM concept, if any, are important in their activity.

There are several definitions of EM to be found in literature. According to the simplest approach (Kraus, Harms, \& Fink, 2010), EM can be described as marketing activities with an entrepreneurial mindset, irrespective of firm size or age. Others claimed that it is the marketing of small firms growing through entrepreneurship (Bjerke \& Hultman, 2002). Beverland and Lockshin (2004) defined EM as effectual action or adaptation of marketing theory to the particular needs of the small business. These effectual actions must simultaneously address many issues: opportunity, innovation, risk, and resource constraints. As Becherer et al. (2008) claimed, EM refers to the marketing processes of firms pursuing opportunities in uncertain market circumstances, often under constrained resource conditions. Morris, Schindehutte, and LaForge (2002) defined the term as the proactive identification and exploitation of opportunities for acquiring and retaining profitable customers through innovative approaches to risk management and resource leveraging for value creation. According to these authors, the EM's roles range from opportunity identification and concept generation to technical support and creative augmentation of the firm's resource base to support innovation. These aims can be reached thanks to the entrepreneur's ability of networking (Gilmore, 2011). Based on a study of American SMEs, Becherer et al. (2008) have extended the definition of EM by saying that it is an organizational orientation having the underlying dimensions of proactiveness, opportunity focus, calculated risk taking, and innovativeness, customer intensity, resource leveraging, and value creation. The EM approach has also been applied by the firms from developing economies. In a study encompassing five cases of Turkish BGs (Kocak \& Ambibola, 2009), the entrepreneurial capital (including the skills of the manager), market orientation, entrepreneurial orientation (EO), and innovation were considered EM components and main sources of successful performance for these firms. A similar approach to defining the EM concept will be used in this study. 
The majority of quoted EM definitions recognize innovativeness as one of the concept's crucial elements. Innovative marketing in SMEs is wider than simply product innovation, it covers the whole range of marketing activity within an enterprise (Gilmore, 2011). According to Becherer et al. (2008), innovation-focused marketing actions allow the firm to concentrate on new ideas that lead to new markets, products, or processes. Product innovation seems to play a crucial role in the SME internationalization (Hollensen, 2011). The successfully internationalizing SMEs are often characterized by flexibility in responding to customer requirements, leading to innovations in their offering and to entering new, geographically distant markets. The importance of this kind of approach to innovativeness was also confirmed by other studies of the Polish BG (Danik, Duliniec, \& Kowalik, 2016; Danik \& Kowalik, 2015). The results of the qualitative study of 10 Polish INVs mentioned above have shown that the maintenance of high product quality and customer focus was treated by managers/founders as key success factors in competition with other internationalized SMEs.

Another element of the EM concept is the international EO, which measures the extent to which the firm's strategic leaders are proactive, innovative, and risk taking in the exploitation of export marketing opportunities (Kocak \& Ambibola, 2009). The EO has been measured in numerous studies, among which relate to international entrepreneurship regard special attention. Weerawardena (2003) and O'Cass and Weerawardena (2009) have applied an international entrepreneurship scale, also called entrepreneurial intensity (EI) scale, which was based on the conceptualization of McDougall and Oviatt's definition (2000) of international entrepreneurship. It contained statements regarding the company approach to competitors, opportunities, risk-taking, and innovativeness. The elements of that scale, regarding EI, are used in this study.

Another element connected with EM application is the characteristic decision-making style, included in the definitions as effectual action (Beverland \& Lockshin, 2004). The so-called effectuation logic has been described by Sarasvathy (2001) in an opposition to "traditional" causation logic. Effectuation logic is characterized by emergent strategies and includes a selection of alternatives based on loss affordability and strategic alliances (Read, Dew, Sarasvathy, Song, \& Wiltbank, 2009). It is connected with little planned action and little or no formal marketing research activity. Effectuation logic suits situations with high risk and uncertainty, while causation logic is more suitable when the future is predictable. In particular, Andersson (2011) has noticed the applicability of this approach to the analysis of BG internationalization. According to his findings, the BG companies do not need the complicated analytical, planning, and control activities for functioning. The entrepreneur-managers' mindset which is called global-vision and their ability to spot opportunities in an international environment are crucial for these companies' success. Moreover, in a study of nine BG companies (Mort et al., 2012), the authors found that a strategy based on an effectuation approach, which was substantially different from conventionally accepted marketing undertaken by established firms, contributed to the achievement of superior market performance in these small firms.

Taking into account the studies mentioned above and the earlier research on the INVs originating in Poland, it is supposed that the crucial elements of EM concept for these INVs in the international environment are innovativeness and EO. Moreover, it is suspected that on the foreign markets, which are characterized by a high level of turbulence and competitive intensity, the Polish INVs may apply effectual approach to marketing decision making. Therefore, the following hypotheses for study are suggested:

H1: The development of innovations influences the INV performance on the foreign markets; 
H2: Product innovations are more important for the INVs than innovations concerning other marketing-mix elements;

H3: The EI influences the INV performance on the foreign markets;

H4: Causal approach to decision making is less frequent in the INV activity than effectual approach.

\section{Materials and Methods}

To explore the hypotheses, the data gathered during two research projects carried out in Spring 2013 and Autumn 2014 at the Warsaw School of Economics have been used. The projects aimed at studying the processes of early internationalization of the Polish SMEs. Two samples of Polish SMEs had been included in the studies. The firms were selected according to the criteria formulated by Knight, Madsen, and Servais (2004), concerning BG companies. They were Polish-based and owned SMEs, which have undergone rapid internationalization (within three years from founding) and have reached at least $25 \%$ share of export sales in the total turnover in the first two years from internationalization beginning. They all belonged to the industrial processing sector of the Polish Classification of Activity and represented its diverse branches (see Table 3).

In 2013, 256 INVs were drawn to join the sample out of the general population of 18,732 SMEs in the available database, with use of randomized algorithm in the software for telephone surveying. In 2014, by means of the same methodology, out of 19,594 records, 105 INVs and 128 gradually internationalized SME companies (GRAD) were drawn. ${ }^{1}$ Following this selection, CATI interviews with export managers/sales directors of the companies were conducted. ${ }^{2}$ The interviews lasted about 25 minutes; they contained closed, semi-open, and open questions regarding internationalization forms, product strategies, and performance on the foreign markets of the studied companies. In 2014, the questionnaire from 2013 was used in a slightly modified (extended) version.

The innovativeness of the studied companies was measured by means of several questions: (a) The companies were asked if they have introduced any innovations in their products or processes; (b) examples of such innovations were cited; (c) the speed of innovation introduction was assessed; (d) the companies were asked if they exceed the competitors with respect to product development and adaptation processes; and (e) if they exceed the competitors with respect to the speed of new product launch (answers to (c), (d), and (e), measured on five-point Likert scales). In addition, in 2014, two questions were included, concerning introducing innovations in the distribution policy and in the promotion policy (dichotomous scales).

The EI was measured by the statements, displayed in Table 1, adapted from Weerawardena's scale (2003).

To learn about the INV decision-making activities, the companies were asked if "on their export market, considering their main product, compared to their main competitor, they are better at ... marketing planning". Moreover, the results concerning the frequency of research conducted before entering new markets were considered as indicator of the approach to planned decision making.

The performance of studied companies has been measured with several indicators. The general performance was measured as a response to the statement "taking into account the situation on local and international markets, they can claim that their company is successful compared to competitors" (answers on a

\footnotetext{
1 The GRADs did not fulfill the criterion of rapid internationalization within three years from founding, but they have reached at least $25 \%$ share of export within total revenues.

2 The interviews were carried out by an external market research agency.
} 
scale: from 1-“definitely no" to 5-“definitely yes"). The financial performance was measured as a response to a statement: "Taking into account the financial indicators (e.g. profitability) of their company, they can claim that it is successful compared to competitors" (answers on a scale: from 1- "definitely no" to 5- "definitely yes"). In addition, in 2014, the following indicator was included: "Please asses the state, in the last two years, of the general financial situation of your company" (three-point scale ranging from: "1"- "loss" to "3"-_"profits").

Table 1

Entrepreneurial Orientation Indicators Used in the Study

\begin{tabular}{|l|l|}
\hline Indicator & Statements in the questionnaire* \\
\hline P.1 & $\begin{array}{l}\text { Statement (1): In dealing with our competitors we use the "live-and-let live" approach... } \\
\text { Statement (2): In dealing with our competitors we have a very competitive "beat-the-competitors" posture. }\end{array}$ \\
\hline P.2 & $\begin{array}{l}\text { Statement (1): In foreign market activity we undertake high risk ventures, if there are chances for high return... } \\
\text { Statement (2): In foreign market activity we avoid risky ventures, even if there are chances for high returns. }\end{array}$ \\
\hline P.3 & $\begin{array}{l}\text { Statement (1): In foreign market activity we often undertake "aggressive" actions, to make our competitors } \\
\text { respond... } \\
\text { Statement (2): In foreign market activity we try not to initiate "aggressive" actions, and rather adjust to the } \\
\text { competitors' moves. }\end{array}$ \\
\hline P.4 & $\begin{array}{l}\text { Statement (1): Before entering a new foreign market we undertake research concerning the chances of success } \\
\text { on that market... } \\
\text { Statement (2): Before entering a new foreign market or engaging in cooperation with a new partner we do not } \\
\text { research the chances of success on that market. }\end{array}$ \\
\hline
\end{tabular}

Note. * The answers to above questions were measured on five-point semantic scales.

\section{Results}

\section{Innovativeness of the INVs}

The following results regarding the innovative activity of INVs were obtained. Of the 256 companies studied in 2013, 161 (63\%) admitted that they have introduced innovations in their products or processes (see Table 2). Moreover, 65 (25\%) of them introduced innovations to the market in a faster way than their competitors. It is also worth mentioning that 110 (43\%) companies claimed that their products were more technologically advanced than competing products, and the offerings of $62(24 \%)$ studied that INVs lacked similarity to any other products currently on the market.

Table 2

Innovation Types and Speed of Introduction by the INVs (2013, Numbers of Answers)

(1) Our company introduces product and technological innovations faster than the competition

Innovation types

(2) Our company introduces product and technological innovations only after the competitors have done so

\begin{tabular}{|c|c|c|c|c|c|c|}
\hline & \multirow[b]{2}{*}{$\begin{array}{l}\text { Definitely } \\
\text { statement } 1\end{array}$} & \multirow{2}{*}{\multicolumn{2}{|c|}{ Rather statement It is difficult to }} & \multirow{2}{*}{\multicolumn{2}{|c|}{ Rather statement Definitely }} & \\
\hline & & & & & & \\
\hline Product innovations* & 16 & 17 & 28 & 3 & 3 & 67 \\
\hline $\begin{array}{l}\text { Purchase of new production } \\
\text { technology }\end{array}$ & 9 & 6 & 23 & 9 & 2 & 49 \\
\hline Process innovations $* *$ & 7 & 4 & 10 & 3 & 0 & 24 \\
\hline $\begin{array}{l}\text { Innovation type not revealed } \\
\text { due to a commercial secret }\end{array}$ & 3 & 3 & 6 & 1 & 0 & 13 \\
\hline Total & 35 & 30 & 67 & 16 & 5 & 153 \\
\hline
\end{tabular}

Notes. * includes: new products, new packaging, improved functionality, product's new form, and shape; ** includes: improving the production process, reducing the energy intake, and using more sophisticated production processes. 
Innovativeness of INVs can also be expressed by their high flexibility in considering alternative markets. In the 2013, sample 44 (18\%) companies indicated that their main product offered on export markets was different from the basic branch of local activity. The examples of such export products included: furniture and metallic goods offered by plastic articles manufacturers or electrical equipment and building services offered by timber and cork goods producers (see Table 3 ).

In the study of 2014, innovation types introduced by the INVs were analyzed and compared with those introduced by GRADs (see Table 4). Two more questions regarding innovative activity were also added, i.e. (1) "Does the company introduce any innovations in its distribution channels" and (2) "does the company introduce any innovations in forms of promotion". It has been found that INVs introduced significantly more product/production technology innovations than the GRADs, and significantly less marketing/promotion innovations than the GRADs. The numbers of companies introducing innovations in their distribution were low among both types of companies studied. Thus, the results concerning product innovations of INVs provide support for hypothesis 2 .

Table 3

Differences Between the Studied INVs' Classification of Local Activity and Main Export Products (2013)

\begin{tabular}{lccl}
\hline $\begin{array}{l}\text { Industry } \\
\text { (Polish classification of activity) }\end{array}$ & $\begin{array}{l}\text { No. of studied } \\
\text { companies }\end{array}$ & $\begin{array}{l}\text { No. of companies indicating } \\
\text { different export product than } \\
\text { local product* }\end{array}$ & $\begin{array}{l}\text { Examples of main export } \\
\text { products }\end{array}$ \\
\hline 1 & 2 & 3 & 4 \\
\hline Metal production & 24 & 9 & $\begin{array}{l}\text { Tools, transportation } \\
\text { equipment, printing services }\end{array}$ \\
$\begin{array}{l}\text { Rubber and plastic goods prod. } \\
\text { Timber and cork goods prod., excl. furniture, straw } \\
\text { articles and materials for kilning processes prod. }\end{array}$ & 20 & 5 & Furniture, metal goods \\
$\begin{array}{l}\text { Machinery and appliances prod. unclassified } \\
\text { elsewhere }\end{array}$ & 17 & 4 & $\begin{array}{l}\text { Electrical equipment, } \\
\text { building services }\end{array}$ \\
$\begin{array}{l}\text { Furniture } \\
\text { Computer, electronic and optical goods prod. }\end{array}$ & 15 & 4 & Metal goods \\
$\begin{array}{l}\text { Food-processing industry } \\
\text { Remaining non-metallic mineral products }\end{array}$ & 36 & 3 & Wooden goods, baskets \\
manufacturing & 6 & 2 & Vehicles, metal goods \\
Paper and paper products manufacturing & 5 & 2 & Rubber goods, chemicals \\
Tobacco products & 2 & 2 & Tools, wooden goods \\
Other branches & 95 & 2 & Pharmaceuticals \\
Total & 244 & 45 & Fuels, machinery \\
\hline Note. * in column "3" and the numbers of companies from column "2" who changed their products for export markets are \\
included.
\end{tabular}

In course of further study, to assess if there is any relationship between innovativeness and performance of the INV, correlation analysis of the innovativeness and performance indicators was conducted (Table 5).

The results in Table 5 show that in 2013, these INVs which exceeded the competitors with respect to product development and were faster at product launch, had better general and financial performance indicators, than the rest of studied INVs. However, the correlation strength between the indicators of innovativeness and performance is quite low. Moreover in 2014, also the occurrence of product and process technology innovations in the INV group was correlated with their performance. Such a correlation was not found in the 
GRAD group. Thus the results concerning innovative activity of INVs, shown above, provide partial support for hypothesis 1 .

Table 4

Differences in Types of Innovations Introduced by the INV and GRAD Groups (2014, One-Way ANOVA)

\begin{tabular}{|c|c|c|c|c|c|c|}
\hline & & Sum of squares & Df & Mean square & $F$ & Significance \\
\hline \multirow{3}{*}{$\begin{array}{l}\text { Innovations in product, } \\
\text { process or production } \\
\text { technology }\end{array}$} & Between groups & 2.601 & 1 & 2.601 & 12.361 & 0.001 \\
\hline & Within groups & 48.609 & 231 & 0.210 & & \\
\hline & Total & 51.210 & 232 & & & \\
\hline \multirow{3}{*}{ Innovations in distribution } & Between groups & 0.038 & 1 & 0.038 & 0.336 & 0.562 \\
\hline & Within groups & 26.099 & 231 & 0.113 & & \\
\hline & Total & 26.137 & 232 & & & \\
\hline \multirow{3}{*}{$\begin{array}{l}\text { Innovations in forms } \\
\text { of promotion }\end{array}$} & Between groups & 3.167 & 1 & 3.167 & 13.533 & 0.000 \\
\hline & Within groups & 54.052 & 231 & 0.234 & & \\
\hline & Total & 57.219 & 232 & & & \\
\hline
\end{tabular}

Table 5

Correlation Between Innovativeness and Performance of the INVs $(2013,2014)$

\begin{tabular}{|c|c|c|c|c|c|}
\hline \multirow{3}{*}{ Innovativeness indicators ${ }^{* * *}$} & & \multicolumn{4}{|c|}{ Performance indicators } \\
\hline & & \multicolumn{2}{|c|}{ Sample of 2013} & \multicolumn{2}{|c|}{ Sample of 2014} \\
\hline & & $\begin{array}{l}\text { General } \\
\text { performance }\end{array}$ & $\begin{array}{l}\text { Financial } \\
\text { performance }\end{array}$ & $\begin{array}{l}\text { General } \\
\text { performance }\end{array}$ & $\begin{array}{l}\text { Financial } \\
\text { performance }\end{array}$ \\
\hline \multirow{3}{*}{$\begin{array}{l}\text { Please indicate if Your company } \\
\text { introduces any product and } \\
\text { technological process innovations } \\
\text { (Yes/No) }\end{array}$} & $\begin{array}{l}\text { Pearson correlation } \\
\text { indicator }(\mathrm{P})\end{array}$ & -0.029 & 0.018 & -0.008 & $0.206^{*}$ \\
\hline & $\begin{array}{l}\text { statistical } \\
\text { significance (p) }\end{array}$ & 0.651 & 0.780 & 0.936 & 0.036 \\
\hline & $\mathrm{N}$ & 249 & 253 & 105 & 104 \\
\hline \multirow{3}{*}{$\begin{array}{l}\text { On our main export market, with } \\
\text { respect to our main product. we } \\
\text { exceed the competitors with } \\
\text { respect to the speed of new } \\
\text { product launch }\end{array}$} & $\mathrm{P}$ & $0.226^{* * *}$ & $0.169^{* * *}$ & na & na \\
\hline & $\mathrm{p}$ & 0.000 & 0.008 & na & na \\
\hline & $\mathrm{N}$ & 241 & 244 & na & na \\
\hline \multirow{3}{*}{$\begin{array}{l}\text { On our main export market, with } \\
\text { respect to our main product we } \\
\text { exceed the competitors with } \\
\text { respect to product development } \\
\text { and adaptation }\end{array}$} & $\mathrm{P}$ & $0.162^{* * *}$ & $0.164^{* * *}$ & 0.033 & 0.074 \\
\hline & $\mathrm{p}$ & 0.012 & 0.011 & 0.740 & 0.453 \\
\hline & $\mathrm{N}$ & 240 & 243 & 105 & 104 \\
\hline
\end{tabular}

\section{Entrepreneurial Intensity of INVs on the Foreign Markets}

The EI indicators, concerning the SME companies, were measured only in the study of 2014. In all studied SMEs, the international EI indicators were at low to medium levels (Table 6).

Indicator P.1 displayed the lowest level, meaning that on average in the 2014 sample, the companies used a "live and let live approach" towards competitors; moreover, the skewness level testifies that there were many companies with level of P.1 even below the mean. The EI indicators' values differed significantly among company types only by the propensity to risk (P.2), the studied INVs had higher propensity to risk than GRADs ( $t$-test of independent samples: $t=2.259, p=0.025$ ). Moreover, the propensity to risk was correlated moderately with the financial performance indicators, but only in the INV group (Pearson correlation $P=0.331$, 
$p=0.001$ for the indicator of financial performance compared to competitors; $P=0.292, p=0.004$ for the indicator of general financial results). Thus, hypothesis 3 was supported only with respect to one dimension of EI.

\section{Decision-Making Approach}

In both 2013 and 2014, the studied companies were asked to evaluate their marketing planning activity by comparing it with that of their competitors. In 2013, only 18\% of studied companies admitted that they were better at marketing planning than their competitors; in 2014 , only $21 \%$ said so ( $42 \%$ of the studied companies did not comment on their marketing planning at all). Moreover, in 2014, the INVs were considerably weaker with respect to marketing planning, than the GRADs ( $t$-test, Table 7).

Table 6

The Level of Entrepreneurial Orientation Indicators in the Studied Sample (2014)

\begin{tabular}{lllll}
\hline $\begin{array}{l}\text { Entrepreneurial } \\
\text { orientation indicator * }\end{array}$ & $\begin{array}{l}\text { Mean level } \\
\text { (scale 1-5) }\end{array}$ & Std. deviation & Skewness & $N$ \\
\hline P.1 & 1.81 & 1.104 & 1.122 & 232 \\
P.2 & 3.49 & 1.192 & -0.728 & 230 \\
P.3 & 3.87 & 0.763 & -0.074 & 228 \\
P.4 & 3.50 & 1.494 & -0.447 & 226 \\
\hline
\end{tabular}

Note. * indicators: P.1 - dealing with competitors, P.2-propensity to risk, P.3-aggressiveness towards competitors, and P.4-foreign market research. Source: Own elaboration.

Table 7

Comparison of Marketing Planning Activity in Different Company Types (T-Test of Independent Samples)

\begin{tabular}{|c|c|c|c|c|c|}
\hline & Company type & $N$ & Mean & Std. dev. & Std. error of mean \\
\hline \multirow{2}{*}{$\begin{array}{l}\text { Company has advantage in } \\
\text { marketing planning compared to } \\
\text { competitors (Scale } \\
\text { "1"-c"definitely not" to " } 5 \text { " } \\
\text {-"definitely yes") }\end{array}$} & GRAD & 128 & 3.50 & 1.527 & 0.135 \\
\hline & INV & 105 & 3.08 & 1.419 & 0.138 \\
\hline \multirow{2}{*}{ Variances } & \multicolumn{3}{|c|}{$\begin{array}{l}\text { Levene's test for the homogeneity of } \\
\text { variances }\end{array}$} & \multirow[t]{2}{*}{$T$-tes } & \\
\hline & $F$ & Significance & $T$-value & & $\begin{array}{l}\text { Significance } \\
\text { (2-tailed) }\end{array}$ \\
\hline Equal & \multirow{2}{*}{3.688} & \multirow{2}{*}{0.056} & 2.176 & 231 & 0.031 \\
\hline Unequal & & & 2.192 & 227.388 & 0.029 \\
\hline
\end{tabular}

Considering the decision-making style, it is also important to refer to the managerial information-gathering indicator (see Table 6, indicator P.4). As it has been found, 56.2\% of the studied companies admitted that they did not research the chances of success before entering the foreign markets. Moreover, no significant difference between INVs and GRADs was found, concerning this indicator, and its mean level on a 1-5 scale was 3.5 (see Table 6). Thus, the above results support hypothesis 4.

\section{Discussion}

According to the international entrepreneurship literature, innovativeness is a central element of the EM concept applied in the international environment. A study by Mort et al. (2012), comprising cases of nine BG firms, has shown that introducing customer-intimacy based innovative products is one of the key EM strategies. 
These authors underlined that studying the EM concept within the INVs is appropriate and they have also identified three more strategies of EM, including opportunity creation, resource enhancement, and legitimacy. Another study, concerning four Finnish INVs, has shown that the core elements of EM strategies in these companies were: innovativeness (value innovation, co-created marketing, and low-cost marketing) and adaptation to local markets. Greater turbulence in the environment seemed to push for even more innovative marketing strategies of the INVs (Hallback \& Gabrielsson, 2013). Furthermore, Read et al. (2009) who focused in their study on marketing decision making in entrepreneurial settings have shown that entrepreneurs are distinguished from inexperienced managers by flexibility in considering more alternative markets, even at the cost of product or strategy change.

The presented study has confirmed the above findings in relation to the Polish INV, i.e., they are innovative with respect to their products and flexible in entering new markets. However, the level of innovativeness of their promotional and distribution activity is low. Even the GRADs display significantly higher innovativeness regarding promotional activity than INVs. Perhaps the explanation is that the product concept is of special importance for the INV entrepreneurs included in this study and they do not have sufficient resources for promotional activity development. Moreover, the approach to promotion, typical of EM concept application, concentrates on direct contacts with customers (Gilmore, 2011), which are probably not treated as "innovative promotional tools".

Furthermore, a study comprising 560 SMEs from the Turkish manufacturing industry (Hacioglu, Erenc, Sule Erenc, \& Celikkand, 2012) has revealed that all dimensions of EM, including innovativeness, were positively related with the performance of these companies. Also Mort et al. (2012) have found that EM contributed to the achievement of superior market performance in the BG SMEs. Only a partial confirmation of the above findings has been found, because the correlation of innovativeness with the performance of Polish INVs was at a low level. However, some authors have suggested that the high marketing performance of an INV results from the fit between the degree of innovativeness of marketing strategies and the internal and external context in which these strategies are implemented (Hallback \& Gabrielsson, 2013). Perhaps in some of the sample companies, the environmental factors did not stimulate high innovativeness of their products, which led to such study results. Therefore, the mediating factors, concerning the Polish INVs' innovative activity influence on performance, require further analysis. Also, the indicators of innovativeness (number, type of innovations, and the speed of their launch) which has been used, may require changing.

The EO of rapidly internationalizing companies has been examined, among others, in studies by Mort et al. (2012), Kocak and Ambibola (2009), O'Cass and Weerawardena (2009), and Weerawardena (2003). It has been found that EO influences positively the performance of such companies and it has been suggested that "entrepreneurial effort" is a key driver of SME internationalization. In this study of the 2014 sample, the EI indicators were at a low to medium level. These findings may suggest that these EO elements are not as important for the Polish INVs as for the foreign-based ones. Perhaps the EO in the Polish INVs should be measured with an altered scale, putting more emphasis on proactiveness and attitude towards risk (Anderson, Kreiser, Kuratko, Hornsby, \& Eshima, 2014). However, the considerably higher level of risk-taking activity of the INVs versus GRADs and its correlation with performance, shown in this study, may suggest that this factor of EO is of special importance for rapid internationalization. 
As for the decision-making approach of the INVs, it was mentioned before, that the lack of marketing planning and information gathering is the characteristic of such companies (Luostarinen \& Gabrielsson, 2006). Moreover, often these firms are not conscious of international knowledge and experience deficiencies at the outset of international activity, due to their managers' excessive optimism and overconfidence (Liesh, Welch, \& Buckley, 2011). This lack of information or incorrect information about foreign markets may lead to "effectual approach" to decision making and cause implementation of emergent strategies. In this study, not only the INVs but also the GRAD companies had low competency regarding marketing planning and displayed low levels of information-gathering activities. Perhaps these results point to lack of experience and overconfidence of the managers. However, they are also in line with the effectuation approach described by Sarasvathy (2001), when in decision making, all that is known by the manager is the company's set of competitive advantage factors and personal skills/relations, which could lead to a potential success, when operating under a given set of circumstances in the international environment. Similarly, in an earlier, qualitative study of 10 Polish INVs, it was found that the so-called "sensemaking activities" of the founders were especially important for setting up the companies and for early stages of their development (Danik et al., 2016). In the majority of those cases, the sensemaking included mainly the clear vision of the founder regarding the potential success of his unique product/service, in connection with his previous experience or the understanding of current global trends. It may be supposed that a similar approach to marketing decision making was used by the Polish INVs described in this study. It is also compliant with the INVs' relatively high propensity to risk, which has been shown above.

\section{Conclusions}

The presented study is one of the first concerning the marketing activity of the INVs conducted in an emerging market setting. It indicates some characteristic elements of the EM concept, which are applied by the INVs from a Central-European market. The majority of internationalizing SMEs which have been studied applied some degree of EM practices, however, product innovativeness and propensity to risk seem to be characteristic especially for the rapidly internationalizing SMEs. Taking into account the research question posed in the introduction, it has been concluded that these elements differentiate the INVs from the gradual SME exporters.

The limitation of this study is that it was conducted as part of a project aimed at characterizing the early internationalization processes among the Polish INVs. Therefore, the results regarding elements of EM concept have an exploratory nature. However, they constitute an important indication for future research. The prospective studies should focus on other elements within the EM concept, employed by the Polish INVs, for example, similar as in research projects conducted abroad, it is worth studying the whole marketing-mix applied by the INVs (Martin, 2009). Moreover, to fully describe the decision-making processes in INVs, a further study is needed, concentrating on the managerial characteristics in the Polish INVs.

\section{References}

Anderson, B. S., Kreiser, P. M., Kuratko, D. F., Hornsby, J. S., \& Eshima, Y. (2014). Reconceptualizing entrepreneurial orientation. Hoboken: John Wiley \& Sons Ltd.

Andersson, S. (2011). International entrepreneurship, born globals and the theory of effectuation. Journal of Small Business and Enterprise Development, 18(3), 627-643.

Becherer, R. C., Haynes, P. J., \& Helms, M. M. (2008). An exploratory investigation of entrepreneurial marketing in SMEs: The influence of the owner/operator. Journal of Business and Entrepreneurship, 20(2), 44-63. 
Beverland, M., \& Lockshin, L. S. (2004). Crafting a competitive advantage: Tempering entrepreneurial action with positioning-based values. Qualitative Market Research, 7(3), 172-182.

Bjerke, B., \& Hultman, C. M. (2002). Entrepreneurial marketing: The growth of small firms in the new economic era. Cheltenham: Edward Elgar Publishing Limited.

Cieślik, J., \& Kaciak, E. (2009). The speed of internationalization of entrepreneurial start-ups in a transition environment. Journal of Development Entrepreneurship, 14(4), 375-392.

Crick, D. (2009). The internationalization of born global and international new venture SMEs. International Marketing Review, 26(4/5), 453-476.

Danik, L., \& Kowalik, I. (2015). Success factors and development barriers of the Polish born global companies. Empirical study results. Journal of East European Management Studies (forthcoming July).

Danik, L., Duliniec, E., \& Kowalik, I. (2016). The Polish born global firms: Founding processes and motives of early internationalization. Transformations in Business and Economics (forthcoming April).

Gilmore, A. (2011). Entrepreneurial and SME marketing. Journal of Research in Marketing and Entrepreneurship, 13(2), $137-145$.

Główny Urząd Statystyczny. (2014). Handel zagraniczny I-IX 2014 . Retrieved from http://stat.gov.pl/obszary-tematyczne/ceny-handel/handel/handel-zagraniczny-i-ix-2014-r-,5,4.html

Hacioglu, G., Erenc, S. S., Sule Erenc, M., \& Celikkand, H. (2012). The effect of entrepreneurial marketing on firm's innovative performance in Turkish SMEs. Procedia-Social and Behavioral Sciences, 58, 871-878.

Hallback, J., \& Gabrielsson, P. (2013). Entrepreneurial marketing strategies during the growth of international new ventures originating in small and open economies. International Business Review, 22, 1008-1020.

Hollensen, S. (2011). Global marketing a decision-oriented approach. Harlow: Pearson Prentice Hall.

Jarosiński, M. (2013). Procesy i modele internacjonalizacji polskich przedsiębiorstw (Processes and models of internationalization of the Polish enterprises). Warsaw: Oficyna SGH (in Polish).

Knight, G. A., Madsen, T. K., \& Servais, P. (2004). An inquiry into born global firms in Europe and the USA. International Marketing Review, 21(6), 645-665.

Kocak, A., \& Ambibola, T. (2009). The effects of entrepreneurial marketing on born global performance. International Marketing Review, 26(4/5), 439-452.

Kowalik, I., \& Baranowska-Prokop, E. (2013). Determinanty powstawania i motywy ekspansji polskich przedsiębiorstw wcześnie umiędzynarodowionych (Determinants of establishment and expansion motives of the Polish born global companies). Gospodarka Narodowa, 4, 41-64.

Kraus, S., Harms, R., \& Fink, M. (2010). Entrepreneurial marketing: Moving beyond marketing in new ventures. International Journal of Entrepreneurship and Innovation Management, 11(1), 19-34.

Liesh, P. W., Welch, L. S., \& Buckley, P. J. (2011). Risk and uncertainty in internationalization and international entrepreneurship studies. Review and conceptual development, Management International Review, 51, 851-873.

Luostarinen, R., \& Gabrielsson, M. (2006). Globalization and marketing strategies of born globals in SMOPECs. Thunderbird International Business Review, 48(6), 773-801.

Madsen, T. K., \& Servais, P. (1997). The internationalization of born globals: An evolutionary process? International Business Review, 6(6), 561-583.

Martin, D. M. (2009). The entrepreneurial marketing mix. Qualitative Market Research an International Journal, 12(4), 391-403.

McDougall, P. P., \& Oviatt, B. M. (2000). International entrepreneurship: The intersection of two research paths. Academy of Management Journal, 43(5), 902-906.

Morris, M. H., Schindehutte, M., \& LaForge, R. W. (2002). Entrepreneurial marketing: A construct for integrating emerging entrepreneurship and marketing perspectives. Journal of Marketing Theory Practice, 10(4), 1-19.

Mort, G. S., Weerawardena, J., \& Liesh, P. (2012). Advancing entrepreneurial marketing: Evidence from born global firms. European Journal of Marketing, 46(3/4), 542-561.

O'Cass, A., \& Weerawardena, J. (2009). Examining the role of international entrepreneurship, innovation and international performance in SME internationalization. European Journal of Marketing, 43(11/12), 1325-1348.

Oviatt, B. M., \& McDougall, P. P. (1994). Toward a theory of international new ventures. Journal of International Business Studies, 25(1), 29-41. 
Polska Agencja Rozwoju Przedsiębiorczości. (2013). Raport o stanie sektora małych i średnich przedsiębiorstw w Polsce w latach 2011-2012 (Report on the state of SME sector in Poland in 2011-2012). Retrieved from http://www.parp.gov.pl/raport-o-stanie-sektora-malych-i-srednich-przedsiebiorstw-w-polsce-w-latach-2011-2012

Read, S., Dew, N., Sarasvathy, S. D., Song, M., \& Wiltbank, R. (2009). Marketing under uncertainty: The logic of an effectual approach. Journal of Marketing, 73, 1-18.

Sarasvathy, S. (2001). Causation and effectuation: Toward a theoretical shift from economic inevitability to entrepreneurial contingency. Academy of Management Review, 26(2), 243-263.

Weerawardena, J. (2003). Exploring the role of market learning capability in competitive strategy. European Journal of Marketing, 37(3/4), 407-429. 